\title{
A Mirror Cracked: Ten Keys to the Landscape of the Calumet Region
}

\author{
Mark J. Bouman
}

\begin{abstract}
Southeast Chicago's Calumet region is many things to many people. Home to wetlands and wildife, mills and millgate communities, landfills and brownfields, it seems to defy casy characterization. This paper argues that it is the jarring juxtaposition of each of these features that best reflects the area. Ten interpretive "keys" or significant landscape-shaping elements form an interpretive frame.
\end{abstract}

Key Words: Calumet region, urban landscape. land use planning, ecosystem planning

Mark J. Bouman (B.A. Valparaiso University; M.A., Ph.D, University of Minnesota) is Professor of Geography and Chair of the Department of Geography, Fconomics, and Anthropology at Chicago State University. From his office window, he can see a relict wetland, a re-used industrial site, a brownfield, and a millgate community in the Calumet region. He is a co-facilitator of the Lake Calunet Ecosystem Partnership.
In the geographical literature, Chicago is often portrayed as a mirror for urban America, with its relentless township and range grid, its social areas rippling away from the Loop in concentric rings and sectors, its humming growth machine vying for power with vigorous neighborhood associations.'

Just as surely, the mirror shatters when it is held up to the heavily industrialized Calumet region at the southern tip of Lake Michigan. It is not for want of trying to capture a coherent picture. The region has been the scene of pionecring studies in ecological succession (Cowles 1901), Pleistocene geomorphology (Salisbury and Alden 1900; Engel 1983), sequent occupance (Meyer 1954; 1956), industrial organization (Appleton 1927), and water transportation (Mayer 1957). More recently, researchers have conducted compelling studies of deindustrialization (Markusen 1985; Bensman and Lynch 1987; Clark 1990), hazardous waste disposal and toxic releases (Colten 1985), community development (Peterman 2000), and recreational and open space landscape development. ${ }^{2}$

But while this multifaceted picture fails to cohere either in the minds of geographers or in the eyes of visitors, it may be that there is a rough kind of cubist logic to the whole. Fach of these studies captures one shard of the regional reality with crystal clarity: Their jarring juxtaposition is what makes the region both unique and archetypal of what happens when industry meets nature in a relatively large slice of urban America.

This paper introduces a brief interpretive frame for this extraordinary ordinary landscape by offering ten interpretive "keys"-or significant landscapeshaping elements-to the landscape. They owe at least as much to the studies noted above, and in the footnotes, as they do to the author's own observations gleaned after 16 years of teaching in the region and working on various regional issues, with an obvious focus on the Illinois side of the state line that bisects the area. ${ }^{3}$ My colleagues and others who live and work in the area could no doubt delete some keys and add others, and that is part of the serious fun that is intended here. The notion that what is important is in dispute is, in fact, part of the point: as citizens and others who work in the Calumet region struggle to rehabilitate the economy and environment, what rises to the top of the agenda depends on how the region is comprehended. This is one take.

\section{Key \#1: The WeT POOL TABLE}

There are two kinds of basement in the Calumet region: those that are wet and those that are about to be. The 35 inches of precipitation that the region annually receives have some difficulty in deciding where to go. At one time the Grand Calumet River that-to put it strongly- "flows" across the landscape, actually had two outlets into Lake Michigan. (One of them was widened to form the main stem of the Calumet River beginning in 1869; the other was obliterated by the construction of U.S. Steel's Gary Works in 1906.) Which mouth was "active" depended on wind and on current-borne sand in Lake Michigan.

From the dunes and mills that line modern Lake Michigan to the enveloping Valparaiso Moraine that rises as much as 200 feet some 20 miles to the 
south, the region occupies the flat former bottom of glacial Lake Chicago. As that lake was drained in stages (over Niagara Falls, or out the spillway through the moraine now occupied by the Des Plaines River southwest of downtown Chicago), a series of small beach ridges paralleling the lakefront developed. These beach ridges served to frame the watery swales that hold roughly a quarter of Cook County's wetlands, lakes such as Calumet, Wolf, and George, and for at least 10,000 years they have also served as dry foot paths through the marshes, bogs, fens, and swamps.

Because Americans have only recently come to appreciate the value of wetlands as habitat, as flood retention, as a filter for contaminants, land as wet as this could be seen as tabula rasa for industrial development, municipal waste disposal, or as "waste" land. With downtown Chicago developing on a constricted site at the mouth of the Chicago River 10 miles to the north, why not move large scale industry here? Why not use it to dump slag or urban waste? What else would it be good for?

\section{Key \#2: Pipe of Peace in Deadstick Pond}

French fur traders used the word "Calumet" to describe the "peace pipe" in broad use throughout the upper Midwest. These pipes consisted of pipestem reeds affixed to a bowl of good Minnesota pipestone. The reeds

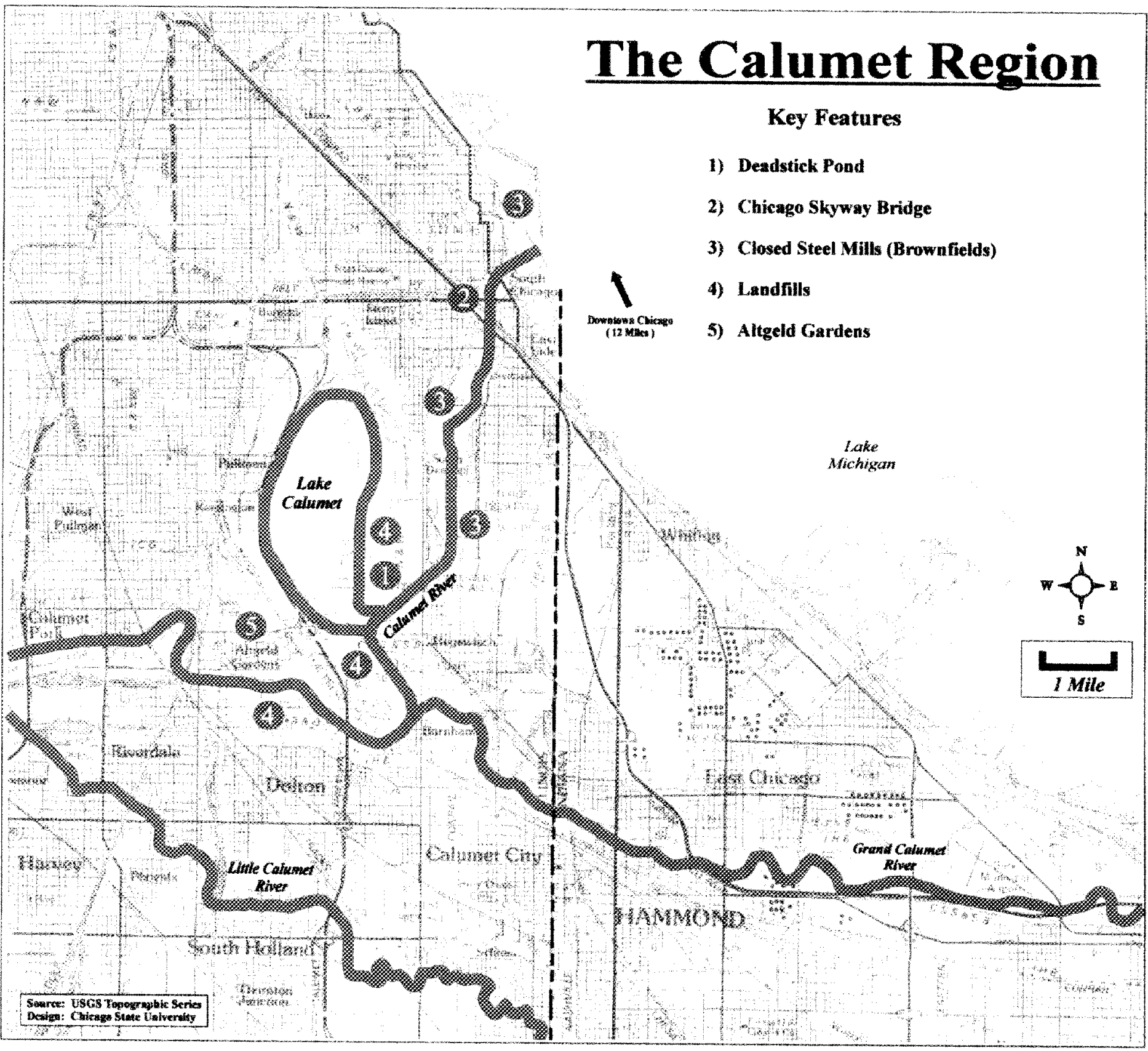

Figure 1. 
grew in many places, but did especially well in the Calumet wetlands. There Potawatomi would canoe the lagoons and ponds of the interdunal swales in search of good material.

That good material includes more than 700 plant species, more than 85 of which that are deemed rare at the state or global scale. Among them is a plant seen nowhere else in the world, Thysmia americana, which was last spotted in 1916. The wetland ecosystems are excellent sources of food, nesting sites, and resting points for a wide variety of migrating birds. Today more than 200 species of birds have been identified in the region, including 18 that are rare at the global or state level. Birders are especially fond of the Ilinois endangered Yellow-headed Blackbird and the Illinois and Indiana endangered Black-crowned Night Heron.

Black-crowned Night Herons nest today in Big Marsh, east of Lake Calumet. To see them, one cannot help but also see the enormous Paxton landfill and Acme Steel Coke Plant that frame the marsh. Birders are also fond of a place just to the south called Deadstick Pond. Mystery novelist Sara Paretsky's fictional detective V.\#I. Warshawski is also fond of this place, where

$A$ lone heron spreads its wings and rises from the marsh. It circles briefly, then heads south, disappearing in the shrouding mist. A handful of purplenecked ducks continues to nibble at delicacies in the fetid water...

The patch of marsh where they rest is small, about half a square mile...The marsh has been filled in with everything from cyanide to slag, with a lot of garbage to give it body...

The locals call the remaining bit of swamp Dead Stick Pond from the eponymous rotting wood which dots it. It appears on no city maps. It is so obscure that Chicago police officers stationed ten blocks away at the Port of Chicago haven't heard of it. Nor have officials at the local Chicago Park District office.

...Conflicting signs tacked to the trees proclaim the area both a clean-water project and warn trespassers of hazardous wastes. Despite warning signs, on a good day you can find anything from a pair of boots to a bedstead dumped in Dead Stick Pond. (Paretsky 1995)

\section{KEY \#3: THE VIEW FROM THE BRIDGE}

Warshawski is an insider. She, like movie director Andrew Davis, who set movies like The Lugitive and The Package in the area, attended South Chicago's Bowen High School. For many people, however, their only experience with the area comes from driving high above it on the Chicago Skyway Toll Bridge that soars above the Calumet River. A quick glance to either side is enough to convince the traveler that this is a decidedly industrial valley, highly dependent on waterborne commerce. Russian, Greek, and Canadian freighters load or unload coils of steel, call at coai docks or grain elevators, or nose cautiously through the river meanders past wonderful trunion bascule bridges.
Some blast furnaces still operate to the south on coke that is carried high over the river on its own suspension bridge from the Coke plant on the West Bank. There is not a Black-Crowned Night Heron in sight. In the far distance to the north is the Loop.

It is worth remembering that a child born in the brand new town of Chicago in 1833 would have been clucked at by just 400 tongues and that only 57 years later would have more than a million fellow citizens in a city whose borders reached the state line. By that time dozens of rail lines skirted the southern edge of the Lake to make the last dash from points east into the city. Those trains burned coal not wood, ran on steel not iron and wood, and pulled a growing number of sturdy steel rail cars or opulent Pullmans. New ways had been found to make the steel and the rail cars cheaply and on a grand scale, and industrialists sought places where large quantities of raw materials could easily reach their plant and be stored before processing in large factory complexes. Such quantities of land were cheaply available further from the city center and for a while, at least, there was the hope that the marshes were also too far for union organizers to set up operations.

So, just as it did at the mouth of the Chicago River, the government got to work to make the Calumet River navigable. Structures were built 300 feet out into the lake on either side of the river to prevent the relentless sand from filling in the river mouth; a channel was dredged in a soggy swale to the junction with the Grand Calumet; and industrial activity began in earnest with the movement of the forerunner of the South Works of U.S. Steel to the river mouth in 1875. Others followed, like Pullman and Hegewisch, Hammond and Inland Steel, Standard Oil and U.S. Steel again by 1906.

One consequence was the continuous dredging and widening of the river system. The Cal-Sag Channel was built in 1912 to connect with the Chicago Sanitary and Ship Canal, the Illinois Waterway, and the Mississippi River. The Indiana Harbor Canal connected to the Grand Calumet River, Burns Ditch connected to the Little Calumet River. By 1965, when the O'Brien Lock and Dam was constructed just south of 130 th Street in Chicago, the drainage system and pattern of flow had been completely altered. It was abetted by a network of municipal sewer feeders and mains that sped storm water to the waterway system. The alteration continues today with active construction of the Deep Tunnel system underlying the llinois portion of the Calumet drainage system. Imagine how the speed and efficiency of runoff has altered the traditional water retention role of the remnant wetlands. (As a side note, those remaining patches of water are occasionally catastrophically influenced by the damming up and subsequent clearing of culverts where they are bordered by roads.)

Meanwhile, industry played a geomorphological role as a great leveler in cutting down the heights and filling in the lowlands. High dunes were destroyed to make way for the Gary Works and the old mouth of the Grand Calumet 
was covered up. Dune mining continued into the $1960 \mathrm{~s}$ at Burns Harbor. On the other hand, enormous amounts of new dry land were made by the dumping of slag and other materials into Lake Michigan and in to the wetlands. Now there were "natural" features with names like Irondale and Slag Valley. The category of "made land" now stands out as a "natural area" almost on the same scale as the Dune and Swale section of the region.

And some day V.HI. Warshawski will take up the case of the disappearing Lake Calumet. Since the Van

Vlissingen plan of 1925-and most actively in the 1950s in preparation for the opening of the St. Lawrence Seawaythe city of Chicago has moved to transform the lake into a grand sheltered harbor. A stay of execution came with the technological obsolescence of general cargo shipping on the Lakes and the shift to containerization. That same shift, I would add, still puts some wetlands in the region at risk because their very openness is still attractive to railroads needing to increase the scale of their intermodal operations.

\section{Key \#4: The GReat SteEl Magnet}

For the better part of a century, the Calumet region seemed to have an almost irresistable pull on industry. To use Colby's term, the region was "centripetally" attractive to industry. He quoted the classic list of site and situational virtues first laid out in Appleton's pioneering study of the iron and steel industry. It included

(1) large parcels of unoccupied land available at low prices..., (2) lake front or river locations, (3) the sandy character of the lake plain which made dredging and excavation for slips a simple engineering task, (4) an abundance of water, (5) marsh or lake areas for dumpage of waste materials, (6) freedom of use, in that control of the land made it practicable to perfect economies of plant layout and operation..., (7) adequate transportation facilities..., these facilities resulting from a combination of lake transportation and belt-line contact with all railroads entering Chicago, and (8) proximity to the Chicago reservoir of labor. (Colby 1933; 1959, 292)

What it all added up to, on the ground as well as from the bridge, was a kind of "technological sublime," to use David Nye's (1994) phrase. As Mayer and Wade (1969) put it Huge blast furnaces and rolling mills, acres of stockpiled ore, coal, and stone, towering grain elevators, the exposed tubing of chemical and paint works, large gantry cranes hovering over wharves and ships, and mile upon mile of drab, almost sullen buildings, crowded in around the water. Fire and smoke charged into the sky as a constant reminder to the world of Chicago's brute industrial strength. Most people were appalled by the dirt, pollution, and ugliness of the scene, but to some there was an elemental beauty to the rough shapes and raw power embodied in this steaming jungle of steel and brick and concrete.
'There is a kind of peace pipe smoke of prosperity here in which the clash of interests was non-problematic." But from the Pullman Strike of 1893 to the Memorial Day Massacre at Republic Sted in 1937 to the struggles to keep the mills open, economic power was always contested, and the contests often had a very local flavor.

\section{Key \#5: Millgate Archiplago}

From the Bush, to Millgate, Irondale, Slag Valley, Hegewisch, Pullman, Altgeld Gardens, Marktown, and Indiana Harbor, the Calumet region is dotted with industrial communities strongly shaped by physical, economic, and social attachments to nearby industries. Some of these communities, like Pullman or Marktown, show the hand of the master planner. Others testify to company or speculative housing. Whatever the case, a trip into any of these neighborhoods is a trip into working class history: national Catholic churches and parochial schools, union halls, restaurants continue to indicate a strong attachment to both local place and distant homelands.

It is not uncommon for neighborhoods such as Hegewisch or Altgeld Gardens to be completely isolated from other communities by wetlands, industries and railroad tracks. For a long time, this isolation enhanced a strong sense of local identity. But the pulse of urban change beating in greater Chicago has also affected the Calumet area. For exampie, the Calumet region lies astride the path of the expansion of the south side Black Belt from near Chicago's Loop to the southern suburbs. South Chicago's African-American population increased markedly during the 1980s and 1990s while the Fast Side (of Chicago) has become increasingly Hispanic. The area to the west of Lake Calumet has become primarily AfricanAmerican, while the area to the east retains pockets of Furopean-American and Mexican-American communities. The currents of race and class of ten serve to further isolate communities that are aiready fragmented geographically.

\section{KeY \#6: RUSTY BROWNHELDS OF DREAMS}

The trip into working class history is all too often just that, as the Calumet region has paid the price of de-industrialization since the early 1980 s with a vengeance. Over 20,000 industrial jobs have been lost on the Ilinois side of the border alone and some landmark industries-South Works, Wisconsin Sted, Rem ir Steel, Pullman-Standard, General Mills-are now closed. In the memorable phrase of David Bensman and Roberta Lynch, what are left are "rusted dreams." From the landscape point of view, what are also left behind are a number of "brownfields." This increasingly popular term refers to abandoned or unused industrial properties with unknown environmental contamination on site. Industrial developers and investors, shying away from the unknown costs of cleanup, are usually attracted to less risky suburban "greenfields" sites.

It is difficult to overestimate the extent of the brownfields problem. Hundreds of sites exist in the city of Chicago." The South Works site covers some two miles of 
prime Lake Michigan lakefront. The Wisconsin Steel site, closed in 1980, is still being cleaned up today. With backing from the U.S. Environmental Protection Agency, the city of Chicago launched a major brownfields recovery effort in 1995. This led to the creation of new state laws that limit the liability of current landowners and that provide specific guidelines as to "how clean is clean." This "tiered approach to cleanup objectives" takes specific account of the future land use of the site: if it is to be industrial in the future, objectives are a little more lenient. But future industrial uses are not guaranteed, as the former regional industrial virtues-water access, large acreages, and so forth-are not as crucial as they were in the context of increased global competition and new steelmaking technologies. Indeed, the epicenter of primary metals manufacture has been migrating eastward to the fringes of South Bend, Indiana, for some time.

\section{KEY \#7: THE HUGGIES OROGENY}

Visitors to the Calumet region will note a range of pyramidal hills reminiscent of Teotihuacan or the Valley of 10,000 Smokes. Nighttime methane flares add to the sense of nuninous mystery. But for most Calumet residents, the hills are no more mysterious than the contents of the kitchen garbage or diaper pail.

Since about 1970, American cities have favored sanitary landfills as the best way to dispose of municipal waste. The Calumet region, already seen as possessing large tracts of "waste" land, seemed prime territory for Chicago regional disposal. At present, some 21 operating or closed municipal landfills dot the region. ${ }^{8}$ They are accompanied by vast acreages given over to sewage treatment. Presently, the highest point of land in the city of Chicago is atop the former sludge drying beds of the Metropolitan Water Reclamation District on lands owned by the Hlinois International Port District. Five years ago, responding to citizen complaints about odors and blowing particulate matter, the beds were capped by a golf course, Harborside International. Since tree roots would penetrate the clay cap, course architects employed a Scottish "links" style design that has made the course very popular in the executive golfing community. Ads for the course typically have a map with north on the left hand border, with the Loop to the left and the course to the right, so as to de-emphasize the course's southerly location.

\section{KEY \#8: TOXIC DOUGHNUTS}

Mrs. Hazel Johnson, the founder and president of People for Community Recovery, a community-based environmental organization located at the Chicago Housing Authority's Altgeld-Murray Homes, has referred to Altgeld's regional position as being at the hole of a "toxic doughnut." To the north are the sludge-drying beds of the Metropolitan Water Reclamation District's Calumet Sewage Treatment Plant, to the east rise the twin mountains of Waste Management's CID landfills, from the west the breezes bring emissions from Acme Stcel's Riverdale plant, and to the south lazes the polluted Little Calumet River. (Mrs. Johnson's doughnut actually has no hole; the very land and groundwater on which the project was built are also seriously suspect.)

There are at least a dozen doughnuts like Altgeld Gardens in the Calumet region-communities whose residents bear a disproportionate price of the region's industrial past and present in a variety of physical ailments. There is no Love Canal here, but by one count there are more than 25 past and present seriously contaminated sites;" there are more than a thousand hazardous substance-producing or -using firms reporting to the Toxic Release Inventory; and there are ongoing concerns about the water, air, and soil quality.

Mrs. Johnson, and dozens of activists like her, are part of a vigorous environmental movement that is alive and well in the region that can count some important victories: Waste Management was forced to close a non-compliant hazardous waste incinerator; large polluting companies that were forced to pay millions of dollars in fines now willingly enter into Good Neighbor Dialogues that focus on pollution prevention; and the city has held the line on new landfill construction for a dozen years. But clearly, even in a landscape rife with community activists, regulators, and non-profit watchdogs, much remains to be done.

\section{KEY 9: THE AIRPORT THAT DIDN'T FLY}

In 1990, Mayor Richard M. Daley of Chicago stunned the region with his announcement that the city would pursue construction of a Lake Calumet International Airport, which would grow to the size and busy-ness of O'Hare." On June 2,2000, the same Mayor and Governor George Ryan announced a comprehensive rehabilitation plan for the Calumet regional environment, including a comprehensive ecosystem management plan, purchase and rehabilitation of two key marshes that are home to the Black-crowned Night Heron, and construction of a showcase Environmental Center in one of them. What happened?

It is argued here that the Mayor, keying in on some of the region's landscape features, was tempted by the prospect of solving them all in one fell swoop. But what he failed to recognize were the people in the landscape $(20,000$ of whom would have had to have been moved to make way for the airplanes). Though the region has long attracted outside study and interest, what the city's proposal did was to bring together environmental and community economic development activists in a significant coalition for the first time. In opposing the airport, they pointed out a number of things: the employment picture had stabilized by the carly $1990 \mathrm{~s}$ in the region, and in fact, a number of thriving companies opposed the airport; the human costs of bulldozing a whole neighborhood (Hegewisch) and a whole municipality (Burnham) would be too high to bear; and the expense of re-routing the Calumet River and lowering the height of a dozen landfills was prohibitive. Even if the airport were built, there was no guarantee that jet-foul- 
ing birds would forget the wetlands they once called home.

Looked at another way, what the activists also began to articulate was a vision of the region's assets that did not require an airport to inprove. The booming success of the Ford Motor Company Taurus/Sable Assembly plant was only one sign of the continued prosperity of some of the region's companies.

\section{Key \#10: Silk Purse National Park}

While the Mayor looked at the Calumet region in 1990 and saw a sow's ear, others, spinning the oppositional momentum into a positive force, began to see a silk purse. By the count of James Landing, geography professor at the University of Illinois-Chicago, some 23 studies and plans for the region were written in the 1990s. Not the least important of these was Landing's own proposal that the area's unique congeries of natural and industrial history made it a candidate for National Park status. What started as a somewhat quixotic and whimsical idea gathered steam and allies as the decade wore on. By 1998, the Calumet Ecological Park Association was able to prevail on Congress to have the National Park Service conduct a feasibility study for the idea. The Park Service demurred on recommending that the area had significant natural assets, but it did suggest pursuing National Heritage Area designation. Such a designation takes advantage of new modes of public-private governance pioneered in the Illinois and Michigan Canal National Heritage Corridor, and it would provide a nationally designated link between that Corridor and the Indiana Dunes National Lakeshore.

In 1999, a Bi-State Calumet Heritage Partnership was created to advocate the formal designation of the area. Meanwhile, other coalitions such as the Wolf Lake Bi-State Alliance, the lake Calumet Ecosystem Partnership, and the Northwest Indiana Regional Forum suggest that multistakeholder advocacy groups are gaining ground in the region. The Lake Calumet Ecosystem Partnership, to name one, advocates a vision of environmental restoration, economic sustainability, and community redevelopment to which an increasing number of governmental agencies, environmental organizations, economic development entities and community organizations are signing on.

In the end, no one key opens up an untarnished mirror of the region. Even within the environmental community, some favor pollution prevention programs, others habitat restoration, and others, some kind of green economic development strategy. Yet, the fact that the groups are talking to each other at all in a context that frankly acknowledges their different interests while seeking common ground, suggests that this last key to the Calumet Region may be the one that will best reflect the area, in all its watery, flighty, hammering, multicultural and contentious complexity.

\section{NOTES}

1. For example, the city's rich history and geography serves as an organizing and introductory device in the widely used introductory urban studies textbook by Barbara Phillips, City Lights: Urban-Suburban America in a Globalizing Society, 2nd ed. (New York: Oxford University Press, 1996).

2. James Landing has authored numerous concept papers for regional land use under the auspices of the Lake Calumet Study Committee and the Fort Dearborn Chapter of the National Audubon Society.

3. Especially influential have been the insights of colleagues such as Fredrick Blum, Janet Halpin, Walter McCarthy, William Peterman, and Michael Siola of Chicago State University, and of James Landing of the University of Illinois at Chicago and Craig Colten of Southwest Texas State University.

4. A sketch of Thysmia americana forms the frontispiece of Floyd Swink and Gerouald Wilhelm's magisterial Plants of the Chicago Region (Bloomington: Indiana University Press, 1995).

5. This is not unlike the view with which William Cronon opens his Nature's Metropolis: Chicago and the Great West (New York: Norton, 1991), pp. 5-6.

6. In Harris and Ullman's seminal "Nature of Cities" paper, the Calumet District is set up as an example of a heavy industrial district which becomes a nucleus for further development. They describe the repellent qualities of the industry found here: "the noise of boiler works, the odors of stockyards, the waste disposal problems of smelters and iron and steel mills, the fire hazards of petroleum refineries, and the space and transportation needs which interrupt streets and accessibility..." Even here, however, these are not sources of conflict per se; Chauncy D. Harris and Edward L. Ullman, "The Nature of Cities," Annals of the American Academy of Political and Social Science 242 (November 1945), 7-17.

7. The city is reluctant to release a specific inventory of sites because the information might jeopardize future development of the site. One employee of the Department of Environment estimated in a personal conversation that the number was over 400 , vary $\mathrm{ng}$ in size from single lots to several hundred acres.

8.15 in Illinois; 6 in Lake and Porter counties, Indiana. City of Chicago, Lake Calumet Airport Feasibility Study, February 1990; People Against Hazardous Landfills Sites, The Environment of Northwest Indiana: Contrasts and Dilemmas (Valparaiso: PAHLS, 1993).

9. These are sites listed in southeast Chicago and northwest Indiana counties on the CERCLIS list established by 
the Comprehensive Environmental Response

Compensation and Liability Act of 1980.

10. For a brief discussion of the Lake Calumet Airport situation in the context of airport planning in general, see Mark J. Bouman, "Cities of the Plane: Airports in the Networked City," in John Zukowsky, ed., Building for Airports: Airport Architecture and Design (Munich: Prestel Verlag and Chicago: The Art Institute of Chicago, 1996).

\section{REFERENCES}

Appleton, John B. 1927. The Iron and Steel Industry of the Calumet District, University of Illinois Studies in the Social Sciences 13, no. 2. Urbana: University of Illinois.

Bensman, David and Roberta Lynch. 1987. Rusted Dreams: Hard Times in a Steel Community. New York: McGrawHill.

Clark, Gordon L. 1990. Piercing the corporate veil: The closure of Wisconsin Steel in South Chicago, Regional Studies 24: 405-420.

Colby, Charles C. 1933; 1959. Centrifugal and centripetal forces in urban geography, Annals, Association of American Geographers 22, reprinted in Harold M. Mayer and Clyde F. Kohn, eds., Readings in Urban Geography. Chicago: University of Chicago Press, 287-298.

Colten, Craig E. 1985. Industrial Wastes in the Calumet Area: An Historical Geography, 1869-1970. Minois Hazardous Waste Research and Information Center, Research Report no. 1.

Cowles, Henry Chandler. 1901. The Plant Societies of Chicago and its Vicinity. Chicago: University of Chicago Press, for the Geographic Society of Chicago, Bulletin no. 2, 1901.
Engel, Ronald J. 1983. Sacred Sands: The Struggle for Community in the Indiana Dunes. Middletown, CT: Wesieyan University Press, 1983.

Markusen, Ann R. 1985. Steel and Southeast Chicago: Reasons and Opportunities for Industrial Renewal: A Research Report to the Mayor's Task Force on Steel and Southeast Chicago. Evanston, IL: Northwestern University, Center for Urban Affairs and Policy Research.

Mayer, Harold M. 1957. The Port of Chicago and the St. Lawrence Seaway. Chicago: University of Chicago, Department of Geography, Research Paper no. 49. , and Richard C. Wade. 1969. Chicago: Growth of a Metropolis. Chicago: University of Chicago Press, 350-352.

Meyer, Alfred H. 1954. Circulation and settlement patterns of the Calumet Region of Northwest Indiana and Northeast Illinois (The first stage of occupance--The Pottawatomie and the fur trader,-1830), Annals, Association of American Geographers 44, 245-275.

1956. Circulation and settlement patterns of the Calumet Region of Northwest Indiana and Northeast Illinois (The second stage of occupance-Pioneer settlement and subsistence economies), Amals, Association of American Geographers 46, 312-356.

Nye, David E. 1994. American Technological Sublime. Cambridge: MTT Press.

Paretsky, Sara. 1995. Windy City Blues: V.I. Warshawski Stories. New York: Dell.

Peterman, William. 2000. Neighborhood Planning and Community-Based Development: The Potential and Limits of Grassroots Action. Thousand Oaks, CA: Sage.

Salisbury, Rollin D., and William C. Alden, 1900. The Geography of Chicago and its Environs. Chicago: Rand McNally \& Co., for the Geographic Society of Chicago, Bulletin no. 1. 


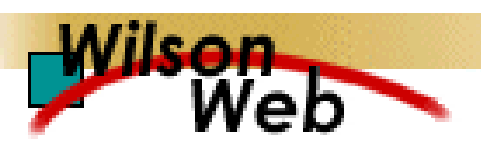

\section{COPYRIGHT INFORMATION}

TITLE: A mirror cracked: ten keys to the landscape of the Calumet region

SOURCE: Journal of Geography 100 no3 My/Je 2001

WN: 0112102347002

The magazine publisher is the copyright holder of this article and it is reproduced with permission. Further reproduction of this article in violation of the copyright is prohibited.

Copyright 1982-2001 The H.W. Wilson Company. All rights reserved. 